
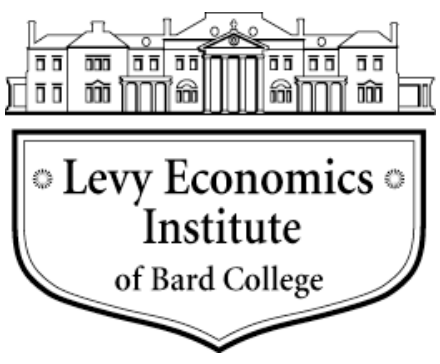

Working Paper No. 857

\title{
Ethno-Racial Origin in US Federal Statistics: 1980-2020
}

by

\author{
Joel Perlmann \\ Levy Economics Institute of Bard College \\ Patrick Nevada \\ Bard College
}

December 2015

The Levy Economics Institute Working Paper Collection presents research in progress by Levy Institute scholars and conference participants. The purpose of the series is to disseminate ideas to and elicit comments from academics and professionals.

Levy Economics Institute of Bard College, founded in 1986, is a nonprofit, nonpartisan, independently funded research organization devoted to public service. Through scholarship and economic research it generates viable, effective public policy responses to important economic problems that profoundly affect the quality of life in the United States and abroad.

\author{
Levy Economics Institute \\ P.O. Box 5000 \\ Annandale-on-Hudson, NY 12504-5000 \\ http://www.levyinstitute.org
}

Copyright (C) Levy Economics Institute 2015 All rights reserved

ISSN $1547-366 X$ 


\begin{abstract}
This paper describes the transformations in federal classification of ethno-racial information since the civil rights era of the 1960s. These changes were introduced in the censuses of 1980 and 2000, and we anticipate another major change in the 2020 Census. The most important changes in 1980 introduced the Hispanic Origin and Ancestry questions and the elimination of two questions on parental birthplace. The latter decision has made it impossible to adequately track the progress of the new second generation. The change in 2000 allowed respondents to declare origins in more than one race; the anticipated change for 2020 will create a single question covering race and Hispanic Origin—or, stated more broadly, race and ethnic origin. We show that the 1980 changes created problems in race and ethnic classification that required a "fix," and the transformation anticipated for 2020 will be that fix. Creating the unified question in the manner the Census Bureau is testing will accomplish by far the hardest part of what we believe should be done. However, we suggest two additional changes of a much simpler nature: restoring the parental birthplace questions (to the annual American Community Survey) and possibly eliminating the Ancestry question (the information it gathered will apparently now be obtained in the single race-and-ethnicity question). The paper is historical in focus. It surveys how the classification system prior to 1980 dealt with the tension between ethno-racial continuity and assimilation (differently for each major type of group); how the political pressures producing the changes of 1980 and 2000 changed the treatment of that tension; and, finally, the building pressure for a further change.
\end{abstract}


In the course of the half century since the civil rights era, the federal government twice made big changes in ethno-racial classification. These changes crystalized respectively in the late 1970s and late 1990s, entering the decennial census in 1980 and 2000. Both these changes will concern us. But the later change, which allowed respondents to declare more than one racial origin, is less central to this paper.

We think it best to conceive of the earlier change in terms of four related features that were new that year (figure 1). First, the best-known and most important change was the introduction of the “Hispanic Origin” question. Second was the introduction of another new question, “Ancestry.” Third, the 1980 Census eliminated two other questions related to ethnicity that had been included for 100 years, namely the parental birthplace questions ("Where was your mother born?,” “Where was your father born?”). Fourth and finally, the 1980 Census introduced a short-lived experiment (rarely noticed today) that avoided a label [i.e., "race”] for the Race question; instead, the question simply read: “This person is...” It was followed by the specific [race] categories.

We briefly discuss the historical background to these changes, and then we take up the efforts of the Census Bureau to reformulate the race and ethnicity questions in use today. The Bureau is conducting an impressive research program on alternatives to these questions. We believe that this research program can best be understood as the Bureau's attempt to apply a fix to the legacy of 1980 and to the problematic aspects of that year's innovations. We believe that the Bureau's testing will probably accomplish by far the hardest part of that fix — a single new ethno-racial question that will combine Race and Hispanic Origin-but we call attention to smaller additional changes that should be part of this fix. These involve restoring the parental birthplace questions and reconsidering the role of the Ancestry question in the new mix of questions on race and ethnicity.

Throughout, our focus is on the meanings of ethno-racial origin that are highlighted in different questions. What was gained and lost with the innovations of 1980 and what do we anticipate will occur in those of 2020? We deal with the historical background to the introduction of new questions, particularly with the array of political struggles that produced them, in enough detail 
to make the changes comprehensible. However, illuminating these struggles is necessary background for the paper, not the purpose.

From a sufficiently distant and abstract perspective, we might say that these innovations of 1980, 2000, and 2020 center on the issue of distant historical origins. How and for whom is it important to track the ethno-racial origins of people whose families have lived in this country for many generations? This question in turn is bound up with the tension between the continuity of ethno-racial membership across generations and its dissolution through assimilation.

Along the black-white divide, the ambiguous institutional and ideological legacies of slavery, Jim Crow, and civil rights shape that tension. And indeed we will see that the situation of African-Americans has served throughout as a baseline for comparison when considering other ethno-racial accommodations. Of course, even the institutional and ideological legacies along the black-white divide play out through processes characteristic of all groups. Among the most important of these processes has been the timing of immigration waves, levels of discrimination, rates of socioeconomic and geographic mobility, tugs between ethno-racial cultures and mainstream outlooks, and the rates of ethno-racial intermarriage. In American history, many peoples have experienced these complex processes with vastly different outcomes. It is this diversity in the connection between historical origins and present condition that the census's ethno-racial questions have struggled to capture.

A second, and seemingly much more straightforward, issue has also pervaded the federal data collection since 1980: Must we track the origins of immigrants' children in particular? Strangely enough, this second question emerged almost inadvertently through the struggles over the first question. 


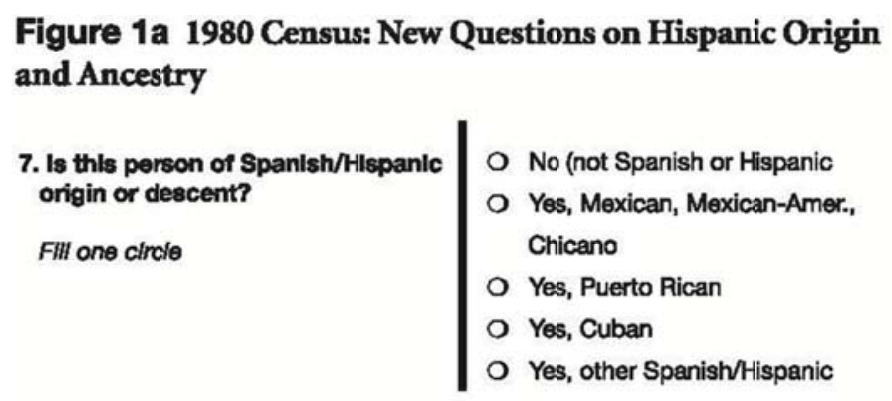

14. What is this person's ancestry? If uncertain about how to report ancestry, see instructions guide.

(For example: Afro-Amer, English, French, German, Honduran, Hungarian, Irish, Jamaican, Koraan, Lebanese, Mexican, Nigerian, Polish, Ukranian, Venezuelan, etc.)

Figure 1b 1980 Census: Question on Race

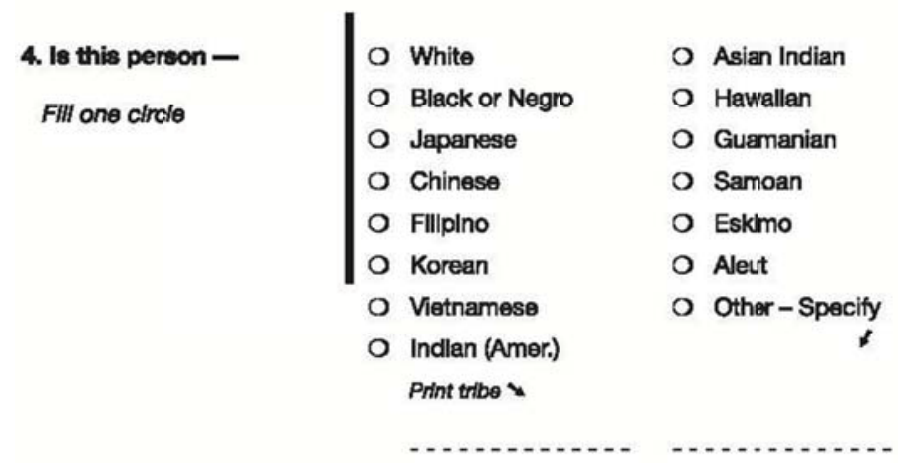

Source: www.census.gov/history/pdf/1980_long_questionnaire.pdf

\section{BEFORE 1980: ETHNO-RACIAL CONTINUITY AND ASSIMILATION IN THE CLASSIFICATORY SYSTEM}

Well before 1950 the statistical system was based on implicit decisions about how long it should track descendants of various ethno-racial groups. In that period, the answers may have had little or nothing to do with ameliorating the condition of minorities, but they did reflect a sense of how quickly and fully different kinds of groups joined the American mainstream. All this would be reexamined after the civil rights era. 
The individual European immigrant groups - the "nationalities” or "national origin” groupswere tracked through two generations. The census captured the specific national origins of the immigrant and the second-generation member through the birthplace and parental birthplace questions. ${ }^{1}$ Even when, in 1909, the US Immigration Commission urged the Senate's Census Committee to adopt a race question for Europeans, the question the Commission desired would have been limited to two generations (Perlmann 2001, n 30 and 32). ${ }^{2}$ The second-generation members of European immigrant groups lost their ancestral language and many other cultural traits; some fraction of these people experienced upward mobility, as did their third-generation children. Outmarriage, too, was fairly common by the second, and even more so by the third, generation. Moreover, the offspring of such intermarriage patterns, the third- or fourthgeneration descendant of a particular immigrant group, was also the descendant of one or more other origins, too (mostly the descendant of other European immigrant groups). After two generations, people of European descent appeared in the census simply as native born of native parentage. The only other ethno-racial origin reported for these people was race; virtually all were white and thus they became part of a huge majority of Americans: native-born whites of native parentage. ${ }^{3}$

Only one other racial group besides whites included a considerable fraction of the American population before 1950: roughly one in nine Americans was reported a member of the black race. And indeed it was only the race question that identified the vast majority of blacks. Birthplace questions told nothing of their origin. Descended from the forced migration of slavery centuries earlier, African-Americans reported themselves simply as native born of native parentage. ${ }^{4}$ The two great groups so classified, white and black, would be distinguished by the race question forever - without, that is, regard to generational standing. To a considerable extent, such tracking

\footnotetext{
${ }^{1}$ Additional data on mother tongue (collected sporadically since 1910) rarely proved useful past the second generation.

${ }^{2}$ Quite apart from assimilative tendencies, there were two other good reasons for not investigating farther back in time than two generations. The first was the number of additional questions required to track origins even one generation further back (to four grandparents' birthplaces). The second was the increasing ignorance on the part of respondents the farther back one probed.

${ }^{3}$ Of course their immigrant and second-generation forbearers had also replied to the race question then, too, as white.

${ }^{4}$ Thus they were native-born black of native parentage. Black migrants from the Caribbean, a small minority of all blacks, were the exception, as many were still first- or second-generation members.
} 
seemed to reflect American social patterns and demographic outcomes. The great majority of blacks remained distinct from the white population, disadvantaged on the important socioeconomic indicators, subject to Jim Crow restrictions in the South, and to powerful discrimination in the North as well. True, despite myths of separate races, there were plenty of interracial offspring, but insofar as they could be identified, they were classified as nonwhiteeither as black or (in most censuses prior to 1930) as mulatto (Perlmann and Waters 2002, 21526). ${ }^{5}$

Not only were blacks the overwhelming majority of nonwhites-the race question also operated most simply and clearly in tracking white and black - it was the paradigmatic racial distinction. But two other kinds of race groups had long been listed by race too, notwithstanding dramatic ambiguities_East Asian immigrants and American Indians. Since the late nineteenth century the census had listed East Asian groups as distinct races. This process began when Chinese immigrants became a focus of national attention. Later other East Asian immigrant groups were successively included as their numbers grew or at least attracted attention: Japanese, Koreans, Asian Indians. Thus immigrants from East Asia were long tracked in radically different ways than were immigrants from Europe. The Europeans were tracked through the birthplace and parental birthplaces questions for two generations. The East Asians, too, were tracked through these birthplace questions for the first two generations. But they were also tracked from arrival and through all subsequent generations (ignoring the generational standing) through the race question. And under the race question those of East Asian origin were labelled as distinct races according to national origin. That is, each respondent's specific racial category was either Chinese, Japanese, Korean, or Asian Indian depending on the birthplace of one's immigrant ancestors, however many generations back.

Originally the race question had been titled the "color" question. Color supposedly distinguished black (African), white (European), yellow (Chinese), and (as we shall see) red (American Indian) peoples. The Chinese category included all East Asians in 1870 and 1880. But a problem arose

\footnotetext{
${ }^{5}$ Indeed, it was this reality that suggested estimating the future population of the country from separate race-based sub-estimates. Of course, insofar as black-white offspring appeared white enough to "pass," they and their descendants might be classified as white.
} 
when Japanese were also added as a distinct category to the "color" question in 1890 . The name of the "Chinese" color category in the census could have been changed at that point to "East Asian,” or "yellow," but this was not the course chosen, probably because it seemed important to keep track of both Chinese and Japanese numbers. It is at this time that the title of the question was changed from "color” to "color or race,” possibly to accommodate the fact that there were now two groups listed of the same "color." ${ }^{6}$ Still, it is difficult to be confident without closer examination of the archival record; the race term's growing role in intellectual discourse could also explain the change.

In any event, when the Japanese category was added in 1890, it appeared right after the Chinese, implying that these were two related categories within one larger "family" or "grand division" of races. And as more Asian national groups were added as race categories in future years, they too were invariably listed in a succession of all East Asian race options. By 1970 the census listed five country categories in this way (Japanese, Chinese, Filipino, Hawaiian, and Korean). In 1980, the Bureau added four more (Vietnamese, Asian Indian, Guamanian, and Samoan). By then, the federal government had also officially announced a pan-ethnic Asian category. Thus the coming of the Asian pan-ethnic group changed very little in the way Asian race categories were presented to the public. ${ }^{7}$

Finally, the race question had tracked the American Indians since the late nineteenth century. A single category was eventually supplemented by a line on which the respondent specified a tribal affiliation. As the indigenous peoples, the American Indians differed from all the other race categories in that the concept of generations since immigration was irrelevant for this group; they were all native born of native parentage. ${ }^{8}$

\footnotetext{
${ }^{6}$ Forms, instructions, and an index of questions may be viewed at: http://www.census.gov/history/www/through_the_decades ${ }^{7}$ OMB Directive \#15. Race and Ethnic Standards for Federal Statistics and Administrative Reporting. May 12, 1977; available at: http://wonder.cdc.gov/wonder/help/populations/bridged-race/directive15.html. Still, no mention of the pan-ethnic category is found in the 1980 Census; probably the Bureau had not gotten around to changing the form because it seemed so minor. All the Asian groups already appeared in succession whether or not they came under a label "Asian.” A decade later the Bureau added a label for the nine Asian categories— "Asian or Pacific Islander (API).” And it added a tenth, “other API.” See: https://www.census.gov/history/www/through_the_decades/questionnaires/.

${ }^{8}$ Unless their forbearers also included European or other immigrant origins as well.
} 
The American Indians also differed from the other racial groups in having by far the largest proportion of interracial unions and multiracial descendants. Here was a conundrum: if the race categories defined people of one race, who was an American Indian? ${ }^{9}$ One answer was that because the American Indians were a very small group, the internal contradiction between racial stability and very extensive multi-raciality could be more easily covered over. But the circle was also squared by invoking criteria specific to the group. Tribal arrangements defined specific qualifications for membership. Among these was typically a rule governing the "blood quantum,” the minimal proportion of one's ancestors who had been tribal members. That quantum was typically well below 50\%. At the same time, the tribes generally supplemented the blood quantum with cultural measures reflecting lifestyle and community recognition of the individual's belonging. The purpose of tribal membership criteria were not to establish race, but the existence of these criteria made it easier for a highly mixed group to be considered members of a single race in federal statistics (Perlmann and Waters 2002, 189-214).

All these arrangements for capturing origins came under pressure after 1965.

\section{THE ROAD TO 1980 (1): THE APPEAL TO HISPANIC ETHNIC ORIGINS}

Demand for more federal data became a hallmark of virtually all ethnic advocacy groups, but it played a special role in the case of the groups that came to be called Hispanic. Since the civil rights era, formerly discrete national origin groups called for recognition and came to be recognized under a broader covering category-Hispanic. True, the covering categories were meant to supplement not supplant national origin designations. Nevertheless, as often as not American discussions eventually came to focus on the more general covering categoryHispanics.

\footnotetext{
${ }^{9}$ One implication became dramatically obvious when the 1980 Census introduced the Ancestry question: the proportion listing American Indian ancestry (typically among other ancestries) but also self-identifying as white was several times as great as the proportion choosing the American Indian race category, and the imbalance has grown since then. Former President Clinton is famously part Cherokee.
} 
A critical feature of this concern with data, especially among the Mexican-American advocates (by far the largest of the "Hispanic" groups), was an insistence on tracking members beyond the second generation. These leaders argued that for the Mexican-Americans of the Southwest, the analogy of European immigrants simply didn't hold. For one thing, for the earliest Mexicans settlers in the area, arrivals had preceded the Anglos; they were rather more like a conquered indigenous people, more like the American Indian than the English or Irish immigrant (Mora 2014).

Of course later migrants had indeed come from Mexico, yet even the descendants of such immigrants were unlike the Europeans. Across the entire century since the American conquest, advocates insisted the Mexican-Americans of the Southwest had suffered far more active discrimination than the Europeans in the North, and remained more isolated (in both language and geography). Thus, despite many generations' standing in the country, the group's disadvantages circa 1965-75 were strongly related to their Mexican origin. And from a numerical standpoint, it was these later-generation descendants that made the MexicanAmericans “America's second-largest minority”-but also "the invisible minority.” In sum, a critical focus of the early advocacy was how to identify Mexican-Americans of the third and later generations, those who were not identified through the birthplace and parental birthplaces questions.

This conundrum had been haunting the Bureau for several census cycles. The 1930 Census had introduced a new race category, "Mexican." Behind that innovation lay an effort to define and highlight the racial status of Mexicans as a mixture of indigenous (nonwhite) and European (white) origins. This new enumeration effort was in turn linked to the aspirations of immigration restrictionists. The immigration Quota Laws of 1921 and 1924 had ignored arrivals from the Western Hemisphere; perhaps another restriction law could complete the task by focusing on the mixed-race status of Mexican arrivals. ${ }^{10}$

\footnotetext{
${ }^{10}$ See Francis-Fallon (2012), Schor (2009, ch. 16), Hochschild and Powell (2008, 59-96), and Gratton and Merchant (2015).
} 
Instead, during the decade following 1930, Mexican-American defense organizations and the Mexican government protested the Census Bureau’s use of the Mexican “race” category, and the State Department joined the call. By the 1940 Census, that race category had disappeared. Instead, the information available in 1940 and 1950 was the same for descendants of Mexican and European immigrants: birthplace and parental birthplaces. ${ }^{11}$ The challenge of whether to identify later-generation Mexican-Americans (and, if so, how should the identification be accomplished) continued to challenge Bureau officials. But it was a lower priority than it had been in 1930 or would come to be again in the civil rights era. The Bureau had no procedure for tracking them. The legacy of the 1930 Census helped ensure that in future years (at least prior to the 1970s) defining Mexican-Americans as a race was not seriously considered. ${ }^{12}$

Thus later-generation Mexican-Americans in the Southwest were critical to the argument for developing new questions about ethnic origin, especially for this, and perhaps for related (Spanish-origin) groups. Conrad Taeuber (1989) had been an important Bureau official involved in the internal discussions and the debates with advocates until his retirement in 1973. In an interview conducted years later, he recalled how "the matter of the identification of what we now call Hispanics became a real political issue.” However elliptically, he touched on the three key issues: first, the "Mexican race" legacy of 1930; second, the mixture of discrimination and isolation in creating a distinctive later-generation group; and third, the fact that the census parental birthplace questions missed this group.

Taeuber: ... As you recall, the 1930 Census had identified Mexicans as a separate race category. That did not go over well with the government of Mexico, and later the Census Bureau went to identifications of Spanish surnames as a way of identifying what we now call Hispanics.

Interviewer: ... we were trying to reconstruct the White-Mexican problem back to 1930, I think, 1930 and 1940.

\footnotetext{
${ }^{11}$ And (in 1940) mother tongue.

${ }^{12}$ There was also the tortured history of the struggle between Mexican-American racialization on the ground and treaty rights to whiteness in courts. See, among others, Fox and Guglielmo (2012). Also, By the 1970s, leaders of various Hispanic groups were attempting to mobilize together. The Puerto Rican population, concentrated around New York City, had increased tenfold between 1940 and 1960. By the late 1960s its leaders too were pressing for more federal help—and for better numbers to demonstrate the need for such help. Their concern was not with latergeneration descendants of course, but they did join a unified call for better Hispanic data. By the late 1960s, the Cuban population was a factor as well. It might be hard to unify them all under a single racial category, particularly given the tendency to think of race and color together.
} 
Taeuber: With the continuing racist problem, and there was a problem primarily because the descendants of the people who were living in the area [at the time of the American conquest of the territories...] The descendants of those people are still to a large extent speaking Spanish, and still to a large extent in Spanish-speaking churches. Irrigation, agricultural—it hasn't really moved out-they preserve their culture. Identifying them as native born of native parentage didn't quite do it.

…

We argued that we had native-born of foreign parentage; that gives us Mexicans of first and second generation, gives us some Puerto Ricans of first and second generation, but we couldn't get away from the people in New Mexico, Arizona, and South Texas. ${ }^{13}$

The Bureau did try to get at this issue during the 1950s and 1960s with post-enumeration counts of Spanish-surnamed respondents in selected areas (particularly the five states with high concentrations of Mexican-Americans). The Bureau collected common surnames from telephone directories of Mexico (as well as Puerto Rico and Cuba). After the census, clerks went through the schedules identifying respondents with qualifying names. This method had the advantages of being an "objective" count. But it was objective only in the limited sense that it rested on a clearly defined criterion rather than on the respondent's self-identification. ${ }^{14}$

But while the surname count was based on a fully defined criterion, the nagging question was whether or not that criterion fully captured the relevant population. Spanish surname did not include families who had changed their names and it did not include women who had married a man who was not of Spanish descent. Moreover, the surname criterion missed the offspring of such people through all subsequent generations.

Of course, name changing and outmarriage typically reflected some degree of acculturation. So the surname criterion might be said to eliminate the more assimilated group members. And if the argument for keeping track of distant origins was that they continued to handicap the group members, were those without Spanish surnames really relevant to the count?

\footnotetext{
13 https://www.census.gov/history/pdf/taeuber_oral_history.pdf. See also Francis-Fallon (2012).

${ }^{14}$ Self-identification was not "objective” in this sense because it was based on unstated and probably poorly defined criteria. One reason for the emphasis on an objective count was that in 1930 the Bureau had discovered that some with origins in Mexico identified not as Mexican but in narrower terms, as Tejano, Californio, or Spanish American.
} 
But no one knew. And in any case, whether distant historical origins handicapped current-day group members was a matter of more or less rather than of yes or no. Consequently, advocates wanted information on as broad a population definition as possible.

Another obvious strategy was to count the "Spanish-speaking" population. But the objections here were very similar to those raised in connection with Spanish surname. If an American of Mexican descent no longer knew Spanish, did it follow that his or her life chances had ceased to be handicapped by that origin? Better to think in terms of "Spanish-speaking origins."

As it turned out, the specific census processes for enumerating the Spanish surname group had far more obvious disadvantages: it covered only five states, and even there on only a sample of the population (restricting utility for local areas). Finally, the Bureau quite simply did not produce many tabulations on the results and requests for special tabulations produced frustrating results. $^{15}$

The Bureau had apparently expected to continue counting Spanish surnames into the 1970s as well (Francis-Fallon 2012), yet by the late 1960s Mexican-American leaders were asking for more and better counts, especially of the population resident in the United States for more than two generations. These leaders were now pressing for self-identification by group members as the way to capture the largest possible number of the later-generation population. After all, this is what was being done for race categories. In 1967, members of Johnson’s cabinet urged the Census Bureau to collect more information on "ethnic origin, particularly the identification of Mexican-Americans” (Francis-Fallon 2012). By 1969 the Bureau had also begun to test questions that relied on self-reports rather than Spanish surname. These tests of self-reports focused on Hispanic origin, but also included a distinct set of questions about ethnic origin

\footnotetext{
15 “Groups like the National Urban League and the NAACP could request data from the Bureau about blacks and receive the information quickly because the question about race was included in all surveys and was tabulated promptly.” Requests for counts of the Spanish-surname data could take years to generate (Mora 2014).
} 
generally. The questions, and the reports on them spoke of "ethnicity," "ethnic origin or descent,” or “Spanish/Hispanic origin or descent” (McKenney and Cresce 1993). ${ }^{16}$

In 1969, Herman Gallegos, then-executive director of the Southwest Council of La Raza, argued that just such self-identification was permitted for "several other minority groups" including Filipinos, Hawaiians, and Koreans, but not for "Spanish-surnamed, Spanish-speaking minorities." Gallegos was referring here to the categories of the race question and drew the implications clearly: “The question titled 'Color or Race' [should] be changed to read 'Race, Color, or Ethnic Origin"”' and it should provide "a breakout of the groups of Spanish heritage such as Mexican-Americans, Puerto Ricans, Cubans, Central Americans, South Americans, etc.” Far from the uses of racial classification in the 1930 Census, this demand to reinstate something close to a racial status for the Spanish groups rested on the recognition that remaining "an invisible minority when seeking assistance and recognition” would be calamitous (Francis-Fallon 2012).

Neither Johnson's cabinet members in 1967 nor Gallegos in 1969 were asking to define Mexican-Americans (or all Spanish-origin groups) as a race. Rather, by the late 1960s "ethnic origin" had emerged as a term that not only social scientists but also those in the federal government and in advocacy groups might use (we will return to this development below). The crucial point was not how to define the ethnic group, but rather the connection between ethnic origin and current-day life chances. For the later-generation Mexican-Americans, that connection seemed to be almost as important as it was for blacks and American Indians. The race question already identified those groups without regard to generational standing in America; something comparable was needed for Mexican-Americans in particular. And yet they could not be counted under the race question, given the earlier history and present attempts at coalition of various Spanish origin groups.

Moreover, group pride lived on well past the second generation, and not only in groups defined as racial, at least not in the America of the late twentieth century. This pride, then, proved

\footnotetext{
${ }^{16}$ See also the codebooks for the November 1969 and November 1979, CPS Surveys (“Technical Documentation”), Johnson Jr. (1974), Lieberson and Waters (1988), Perlmann and Waters (2002, 9), and U.S. Bureau of the Census (1971, nos. 213 and 221).
} 
another source of interest in ethnic counts beyond the second generation, an interest that joined the policy justification (stated in terms of the connection between later-generation ethnic origins and life chances).

However, Census Bureau officials were skeptical about trying to capture ethnic membership. How would the respondent know all the relevant origins prior to the grandparents? How would he or she choose which of several origins to list? Would all who qualify even identify with the terms indicated on the form? And what of the strength of ethnic ties? Merely answering a question about origins did not imply that the ties had the same relevance for all. In other words, while advocates spoke of the isolation, discrimination, and continued distinctiveness of groups past the second generation, officials wondered about levels of assimilation, intermarriage, and multiple origins among the same population.

And yet, as Gallegos's prescient observation (quoted above) suggests, the Bureau was caught in something of a bind: the categories of the Race question, categories that went far beyond the black and white paradigm, did define membership in distant origin categories and did so by selfidentification. But should this kind of classification be extended still further to groups not listed on the race question?

By the late 1960s, Spanish-origin organizations were routinely finding congressional allies. And at the end of that decade, the Nixon White House apparently caught the Bureau off guard in announcing that the 1970 Census would include a nationwide question on "Spanish Origin" (Francis-Fallon 2012; Taeuber 1989). ${ }^{17}$ It was too late to put the question on the form for the $100 \%$ enumeration (the "short form”) but it was added to the 5\% sample form (the "long form”).

During the first half of the 1970s the Bureau faced bitter criticisms-including court casesabout undercounts, lack of Spanish-language forms, and a general lack of attention to the

\footnotetext{
${ }^{17}$ Actually, the new question was only one of several ways the Bureau counted the Spanish origin population in the 1970 Census cycle. In the five Southwestern states, as before, it also ascertained Spanish surname. In New York, New Jersey, and Pennsylvania it asked about whether respondents or their parents had been born in Puerto Rico. And finally in most states it also asked about Spanish mother tongue. Naturally, each count diverged from the others, since each used a different definition of the target population.
} 
Spanish origin population. President Nixon replaced the Director of the Census Bureau; the new director created closer links to various ethnic and racial groups, including Hispanics in particular, with boards of ethnic stakeholders (Mora 2014; Francis-Fallon 2012). Congressional advocates submitted several bills across the first half of the 1970s, and held hearings concerning better data. In June 1976, Congress passed a resolution requesting the Office of Management and Budget (OMB) to "develop a Government-wide program for the collection of data with respect to Americans of Spanish origin or descent” (Mora 2014; Francis-Fallon 2012). As historian Francis-Fallon notes, that this was "the only law of its kind, mandating data collection for a specific ethno-racial group" (Mora 2014; Francis-Fallon 2012). The Act called for "a reliable and comprehensive socioeconomic profile" for Spanish origin "on par with that available for the general population of the United States” (Mora 2014; Francis-Fallon 2012).

Officials at OMB had been aware of the need to standardize ethnic and racial data collection since the beginning of the decade (Mora 2014; Francis-Fallon 2012). In 1977, it released Directive \#15. By 1980, the events of the late 1970s—-the legislation and the OMB Directivehad resulted in a distinct Hispanic Origin question, along with the Race question, on the census form sent to $100 \%$ of the population.

\title{
OMB DIRECTIVE \#15
}

Very near the beginning of Directive \#15: Race and Ethnic Standards for Federal Statistics and Administrative Reporting, the OMB authors note what might be called the usual disclaimer:

\begin{abstract}
These classifications [race and ethnicity and the particular categories under each] should not be interpreted as being scientific or anthropological in nature, nor should they be viewed as determinants of eligibility for participation in any Federal program. They have been developed in response to needs expressed by both the executive branch and the Congress to provide for the collection and use of compatible $[\ldots]$ racial and ethnic data by Federal agencies. (OMB Directive \#15)
\end{abstract}

Beyond this disclaimer, the directive does not offer definitions for either race or ethnicity. This is more striking in the case of ethnicity, since this conception did not have a lineage in federal 
statistical usage the way race did. Moreover, as race and ethnicity remain undefined, so too does the relationship between them. Past arrangements and beliefs, not a new beginning, best explain why, for example Hispanics will be deemed to comprise an ethnicity and Asians a race.

Indeed, the directive only mandates attention to ethnicity for one purpose: distinguishing Hispanics from non-Hispanics. Still, the text does mention that beyond the minimum mandated categories listed under race and ethnicity, federal agencies might find it useful to include additional categories under one or both.

The Directive offered two options that agencies might use for gathering the mandated race and ethnic information.

To provide flexibility, it is preferable to collect data on race and ethnicity separately. If separate race and ethnic categories are used, the minimum designations are:

a. $\quad$ Race:

—American Indian or Alaskan Native

—Asian or Pacific Islander

-Black

-White

b. Ethnicity:

-Hispanic origin

—Not of Hispanic origin

When race and ethnicity are collected separately, the number of White and Black persons who are Hispanic must be identifiable, and capable of being reported in that category.

If a combined format is used to collect racial and ethnic data, the minimum acceptable categories are: 
—American Indian or Alaskan Native

—Asian or Pacific Islander

—Black, not of Hispanic origin

-Hispanic

—White, not of Hispanic origin.

In the "preferable" option A, four races and two ethnicities (Hispanic and not Hispanic origin) were fully independent, giving a total of eight possible categories $(4 * 2)$. But in the acceptable option B, there were only five categories (four races and Hispanic origin). The formulations suggest two somewhat different meanings for race and ethnicity. In option A the two concepts can be understood as distinct (if undefined) concepts. In option B they are melded into ethno-racial categories that cannot be disentangled into fully distinct concepts. $^{18}$

No doubt OMB officials assumed that the Census Bureau would use the more refined two-question version, and it did. The census also continued to include a miscellaneous category for "some other race." This residual category had been available in every decennial census since 1910, but it would play a new role in 1980 and the following decades. Very large numbers—-many millions—of Hispanic respondents were recorded as declaring themselves in this residual race category. We return to this issue and its influence today in the last section of this paper.

Defining Hispanic Origin as an ethnicity, of course, would have been difficult indeed had the term not been familiar well beyond the social sciences by the late 1970s (a point taken up in the next section). But notwithstanding the popular familiarity with the concept of ethnicity, few people realize that there is an "ethnicity" question and a "race" question on the decennial census. It has become simpler and more relevant to speak of the Hispanic

\footnotetext{
${ }^{18}$ Note, too, the privileged status of Hispanic Origin compared to race in option B. In this reduced set of categories no Hispanics would appear in any of the four other ethno-racial categories. This exclusion is stated explicitly for whites and blacks, and is implicit for the other two categories. Indeed, option B would reduce the prior years' counts of all races. This is the starkest evidence of the successful struggle to overcome "invisible minority" status for the Hispanic groups.
} 
Origin question rather than of an ethnicity question that asks only whether or not one is Hispanic. It is the operational category, not the wider classificatory conception, to which people refer. $^{19}$

\section{THE ROAD TO 1980 (2): WHITE ETHNICS AND THE ORIGIN QUESTION}

The Hispanic Origin and Ancestry questions emerged simultaneously. And this fact helps drive home the point that the Hispanic Origin question must be considered in connection with ethnic origin and not only an Hispanic issue. Prior to these questions, the terms "ethnic" or "ethnic origin" or "ethnicity” had not been used for census questions. Nor had the terms been mentioned frequently (let alone systematically) in census reports prior to the 1970 s. $^{20}$ Yet Hispanic Origin and Ancestry would both be defined by reference to ethnicity and ethnic origin. Also, both, like race, would ignore generational standing.

The focus in both the Hispanic Origin and Ancestry questions, as in the Race question, is on membership in a people without regard to how distant the origins. The implicit policy justification for such questions, and especially for the Hispanic Origin question, is that latergeneration ethnic origins, rather like African origins, continue to influence life chances.

This analogy of various historical origin groups to African origins seemed strongest for the three major nonwhite minority groups: those that would be called Hispanics, Asians, and Native Americans (Skrentny 2004). ${ }^{21}$ However, all three would be counted in this way either on the Race question (blacks, Native Americans, and Asians) or on the Hispanic Origin question.

\footnotetext{
${ }^{19}$ This development is weirdly reminiscent of events two-thirds of a century earlier. In 1910, Census Director Durand introduced the mother tongue question as the alternative to counting immigrant groups as "races." He did so by stressing a new terminology for the counts, in particular that mother tongue was the measure of "nationality" (in the sense of peoplehood rather than citizenship). And yet, very soon this line of argument had all but disappeared. In its questionnaires and then in its publications the Bureau rarely, if ever, mentioned nationalities, only mother tongues (Perlmann 2001). Many Americans eventually followed suit.

${ }^{20}$ The only partial exception was to invoke a vague terms like "ethnic stock."

${ }^{21}$ We return to this theme in detail below.
} 
The Ancestry question was unique in producing specific national origin data only in connection with later-generation descendants of specific European (white) peoples. Why then did the Ancestry question come into being? There are, we believe, three reasons.

First, the Census Bureau officials must have been uncomfortable with introducing a new question about origins that focused on only one ethnic (or pan-ethnic) group-Spanish origin. Whatever the legislative and OMB interest in such a question, it would have been a dramatic departure from any origin question the Bureau had introduced in the past, and a step hard to justify on demographic grounds alone. Partly for this reason, the Bureau began testing a general ethnic origin question at the same time as a Spanish origin question (1969). This simultaneous testing lasted through the early 1970s.

Indeed, even when the Bureau had submitted to White House pressure in 1970 and added the Spanish origin question to the 5\% sample form, the wording of that question was a revealing mixture of a focus on specific and general ethnic origins. The question was not labelled as the Spanish or Hispanic origin question. Rather the question asked "Is this person's origin or descent...” and it is followed by six categories: "Mexican; Puerto Rican; Cuban; Central or South American; Other Spanish; No, none of these.”

By the end of the 1970s, however, the legislation calling for data by Spanish Origin, followed by the OMB mandate to collect data on Hispanic Origin, led to the 1980 version of the question that read, “Is this person of Spanish/Hispanic origin?” And the question would appear on the 100\% enumeration. Nothing like that would support the Ancestry question, and yet it was added to the form that went to the sampled households that year; it had been tested in the November 1979 CPS.

In sum, one crucial reason for the introduction of the Ancestry question was that it was the generalized form of the Hispanic Origin question, even if it did not have behind it the legal standing or the degree of ethnic pressure that supported the latter question. But there were two other factors at work as well. A second reason for the Ancestry question's success was a white ethnic variant of the political pressure of the Hispanic groups. A third, closely related, reason 
was the perceived continuum along which fell the white ethnic and the nonwhite minority groups.

The descendants of southern and eastern Europeans in particular pressed for the Ancestry information. Their families had experienced a racialized discrimination as "the wrong kinds" of European races, and had experienced these travails more recently than descendants of earlier immigrant waves. And so, connections between ethnic origins and life chances probably existed for the southern and eastern European ethnics more than for other Euro-Americans.

Nevertheless, it is also true that the pressure for such data did not derive only from an interest in the group’s life chances. Ethnic pride played a role of course, but also resentment at the increasing attention of the federal government to black and other nonwhite minority groups.

By the late 1960s a quite specific meaning for "white ethnic" had taken hold. It applied loosely "to the mostly Catholic [or Orthodox Christian] immigrants or persons with ancestry from eastern or southern Europe [...] while Jews and Catholic Irish Americans are on the boundaries.” WASPS and Scandinavians were excluded (Skrentny 2004, 275). Until the 1960s, they had had precious little incentive to demand that the federal government pay more attention to them. Over the decades (and generations) their cultural distinctiveness had declined and their economic condition had been improving. Still, most lived in the northern cities, many in working-class neighborhoods close to where great numbers of black migrants from the South had been settling since the 1940s. This uneasy proximity accentuated their tendency to refer to themselves simply as whites, rather than as Italian, Polish, or Slovak. But the meaning of this tendency should not be exaggerated. There is no reason to claim that the identities and loyalties as members of specific national origin groups were suddenly lost. A person could easily enough define oneself as white or Italian, depending on the specific social context.

John Skrentny’s (2004) authoritative study, The Minority Rights Revolution, illuminates the many reverberations related to recognition of the white ethnic movement and in particular their relation to the process already described by which four protected groups came to be defined as legally protected for affirmative action purposes. During the years beginning in 1967, there was considerable public attention to these white ethnics. In 1967 the undersecretary of Housing and 
Urban Development gave a speech on the problems of the "average white ethnic male"economic insecurity, life adjacent to a black ghetto, observing antiwar protests at the universities (which violated his values), and generally feeling neglected. Various foundations, universities, and other organizations created a "National Project on Ethnic America." By 1971, the Ford Foundation was providing nearly $\$ 1$ million for efforts to ameliorate the fact that "great numbers of working-class Americans have not been at the center of recent social concerns" and to increase understanding of "the continuing role of ethnicity in American life." In 1969 Newsweek reported on "The Troubled American Majority" (with much attention to the white ethnic) and in 1970 on "Rising Cry: Ethnic Power.” In 1972 Congressional Quarterly Weekly Report examined “Campaign '72: The Rising Voices of Ethnic Voters” (Skrentny 2004, 278-81 and 296).

And last but not least, white ethnic organizations also lobbied to some extent to be included in affirmative action programs. At a federal hearing an Italian-American leader made the broader point to the Equal Employment Opportunity Commission (EEOC) Chairman that not all minority groups who had suffered were listed. Omitted were "minority groups such as Italian-Americans, Polish-Americans, German-Americans, Irish-Americans, Jewish-Americans, and others.” Some Congressmen also supported the claim (Skrentny 2004, 281-83 and 293-95). The members of these white ethnic groups had often been listed among "minorities" well into the 1950s — either in ethnic terms or as Catholics and Jews. Then too, the Civil Rights Act explicitly prohibited discrimination in employment on the basis of "race, color, religion, sex, and national origin." How then was the decision made to exclude the white ethnics from the minorities protected by affirmative action? How did it come about that Hispanics, Asians, and American Indians would join blacks on that list but the white ethnics would not? Skrentny $(2004,289-90)$ illuminates the interplay of minimal data, assumptions, federal officials, politicians, and ethnic organizations. He summarizes:

There was some undefined standard of oppression and victimhood that guided national policy relating to affirmative action [...]. Women, Asians, Latinos, and American Indians had suffered like blacks and thus could be analogized to them. White ethnics had not suffered enough and the analogy did not work. 
Skrentny acknowledges that Nathan Glazer and Arthur Mann argued at the time for a different explanation: that the white ethnics generally were well on their way to assimilating into a (white) mainstream. Consequently the leaders of the white ethnic organizations who argued otherwise really lacked a meaningful clientele, but he counters that the link between leaders and clientele was complex for all groups. In general, white ethnics had "advocates in Congress and in the White House. Politicians wanted their votes and saw them as an economically disadvantaged group.” One explanation for the white ethnic failure to be included in affirmative action is policymakers' "standard of oppression" just mentioned; another, Skrentny suggests, is that politicians could also relate to the white ethnics on other bases: class, religion, union membership, and so on. "National policy therefore racialized [white] ethnics as privileged whites and they remained close but just outside the minority rights revolution” (Skrentny 2004, 275314).

In any case, the crucial issue for us here is not why the white ethnics were excluded from the lists of minorities counted for affirmative action purposes. Rather, what matters for the intellectual and political context at the end of the 1970s is simply the fact that the white ethnics were in fact (in Skrentny's perceptive formulation) "close but just outside" relevant discussions of minority rights. These white ethnics therefore had some sort of presence in the discussions of the time concerning the importance of ethnic descent-their levels of wellbeing as well as their "unmelted" nature, the seeming tenacity of their origins well past a group's second generation in American life.

The Bakke case called attention to this continuum of ethno-racial minority groups at the end of the 1970s. Many white ethnic groups filed briefs opposing the UC Davis Medical School's affirmative action policy. A particularly important brief was filed on Bakke's behalf by three Polish organizations. This brief argued that the university did not consult data about which groups had suffered most. Instead it "began with a list of preferred groups already in mind without a comprehensive study of which ones had been discriminated against.” After all, national origin as well as race was a prohibited basis of discrimination; it was possible that good data on under-representation would show that Polish-Americans should be on the list of groups that had 
indeed suffered most. Moreover, the brief pointed out, racial was not a more prohibited form of discrimination than that against national origin (Skrentny 2004, 291).

The Bakke decision was famously split, but Justice Powell’s opinion provided the crucial swing vote and governed the decision. Powell's famous concerns about the redress defense sound eerily like those in the Polish-American brief:

[T]he difficulties entailed in varying the level of judicial review according to a perceived "preferred" status of a particular racial or ethnic minority are intractable. [...T]he white "majority" itself is composed of various minority groups, most of which can lay claim to a history of prior discrimination at the hands of the State and private individuals. Not all of these groups can receive preferential treatment and corresponding judicial tolerance of distinctions drawn in terms of race and nationality, for then the only "majority" left would be a new minority of white Anglo-Saxon Protestants. (Skrentny 2004, 174-75)

Powell also commented in a note that,

The University is unable to explain its selection of only the four favored groups-Negroes, Mexican Americans, American-Indians, and Asians-for preferential treatment. The inclusion of the last is especially curious in light of substantial numbers of Asians admitted through the regular admissions process. (Skrentny 2004, 175)

Thus in the last years of the 1970s, arguments about the continuum of minority groups, explicitly including the white ethnic groups, was being forcefully expressed at the highest governmental level. This continuum was very likely something about which policy-oriented demographers at the Census Bureau would have been aware. ${ }^{22}$ And given that continuum, Bureau officials would have had a strong rationale for not limiting counts of distant ethnic origins only to Hispanics.

\footnotetext{
${ }^{22}$ Writing in 1993, in a section on "Data Needs" (that the Race, Hispanic Origin, and Ancestry questions address) McKinney and Cresce noted elliptically, "Ancestry information is not explicitly required by any federal legislation or directive. However, recent US Supreme Court decisions extending the coverage of affirmative action and equal employment provisions to 'ethnic' groups other than those traditionally interpreted to be the focus of legislation have shown the importance of ancestry data." See "Measurement of Ethnicity...” in McKenney and Cresce (1993).
} 
The ethnic origins of white groups did not rise to the same level of political or legal concern as those captured in Race and Hispanic Origin categories did.

We have identified three reasons for the introduction of the Ancestry question: 1) the sense that if ethnic origins were a reasonable topic for the census, they should not be limited to only one kind of ethnic group (Hispanics); 2) the political pressure from white ethnic groups; and 3) the perceived sense of a continuum extending across the white ethnic and nonwhite minority groups.

How strong was the drive for the Ancestry question? This is not easy to answer. In an oral history interview, Louis Kincannon, who was working at the OMB in the years before 1980, but would later serve as Deputy Director and still later as Director of the Census Bureau, recollected the period finalizing the 1980 questionnaire. He notes that the Ancestry question was saved by President Carter's White House staff in an election year. ${ }^{23}$ And further, he recalled only moderate support for the question from the Census Bureau officials with whom he (at OMB) was interacting. But it is worth attending to his description on that point:

\begin{abstract}
Given the objective in the Carter Administration of reducing Federal paperwork, we $[\mathrm{OMB}$ ] just about had to cut something out ... [and one question we urged be cut] was ancestry [...] Essentially, it was not a very scientific question; it was sort of an opinion poll- "What would you like to be identified with?"-you know, the Poles or the Scots or the whatever. Since it didn't have any scientific basis and didn't have any objective answer that you could evaluate, we took a rather dim view of it. In fact, informally, the Census Bureau didn't seem to express much enthusiasm for it. It had been a substitute for a question called "mother tongue," which had been used traditionally to analyze and monitor immigrant population. So we recommended eliminating [...] [the ancestry question] and some others. The political people in the Carter Administration [rejected most of our recommendations for cutting questions...] [T]he ethnic desk in the White House insisted that the ancestry question go on the census. (Bohme 1992)
\end{abstract}

Kincannon's recollections indeed suggest that presidential politics saved the Ancestry question. He is less definitive on the attitude of Census Bureau officials to that question. Indeed the notion

\footnotetext{
${ }^{23}$ On this episode, see also Skerry (2000, 37) and Glazer in Perlmann and Waters (2002, 318-26), especially pages $322-24$.
} 
that the Ancestry question "had been a substitute for a question called mother tongue" may well have been a common view at the Census Bureau. Like Ancestry, mother tongue had been a way to explore historical origins through measures other than country of birth or parental countries of birth. The mother tongue question had been introduced in 1910 as a way to capture ethnic origins in a period when these were not well reflected in national origins-especially among the many peoples coming from the multinational empires of eastern European. And both questions were similar in attempting to capture ethnic origins that might go back several generations. Indeed, in 1910 and 1920 the census asked not only for mother tongue but also (among the foreign born) for mother's and father's mother tongues.

Kincannon may well be right that the Bureau officials did not have great faith in the Ancestry question, but they may not have had any greater faith in the Hispanic Origin question. If the latter was going on the census questionnaire, they may have reasoned that the more general form of the question should be there too. These questions were conceptually very similar in exploring distant ethnic origins.

\section{THE CENSUS ORIGIN QUESTIONS, 1980}

To appreciate Ancestry as a generalized Hispanic Origin question, consider the instruction that accompanied each in the 1980 Census.

\section{Question 7. Hispanic Origin}

A person is of Spanish/Hispanic origin or descent if the person identifies his or her ancestry with one of the listed groups, that is, Mexican, Puerto Rican, etc. Origin or descent (ancestry) may be viewed as the nationality group, the lineage, or country in which the person or the person's parents or ancestors were born.

\section{Question 14. Ancestry}

Print the ancestry group with which the person identifies. Ancestry (or origin or 
descent) may be viewed as the nationality group, the lineage, or the country in which the person or the person's parents or ancestors were born before their arrival in the United States. Persons who are of more than one origin and who cannot identify with a single group should print their multiple ancestry (for example, German-Irish). (US Census Bureau 1986, ch. 12, p. 15).

The two questions ask about origin in identical terms. Both concern the group with which the respondent "identifies." Both relate the identification to the same three terms (ancestry, origin, or descent). Both define the meaning of these three concepts with identical words (last sentence, Hispanic Origin; second sentence, Ancestry).

In a world of single origins, the respondent to the Ancestry question would have only one ancestry to report. In that world, there would be little advantage to a Hispanic Origin question distinct from the Ancestry question. But in American society, with its intermingling of peoples, many respondents not only list multiple origins, they also list only some of those origins. The Hispanic Origin question forces attention to one kind of origin: are you Hispanic—yes or no? The results support the expectation: substantially higher numbers of people answer yes to the Hispanic Origin question than mention a Hispanic group in reply to the Ancestry question. As a remedy for earlier inattention and notoriously partial counts, the Hispanic Origin question was meant to demonstrate a new departure in which the fullest possible counts would be obtained for this population. And since Hispanic Origin counts were used for affirmative action purposes, the new question, like Race, had to be included on the short form, used in the $100 \%$ enumeration. Since the Ancestry counts had no such role, the question (like most census questions) could be left to the long form completed by only a sample of the population. ${ }^{24}$

\footnotetext{
${ }^{24}$ McKenney and Cresce commented in 1993 that "the Bureau [unsuccessfully] tested [for the 1990 Census] alternative [question] formats that would allow persons of all ethnic groups to report on a 100 percent basis. The Bureau also considered a combined Hispanic origin and ancestry question but did not test this approach based on the advice received through consultations." A footnote attached to that sentence reads: "Participants at a 1985 Conference on Race and Ethnicity strongly recommended that the Census Bureau not test a combined Hispanic/ancestry question because the proposed question would be confusing and divisive to the public and also would not provide accurate reporting of Hispanic individual groups on a 100 percent basis" (McKenney and Cresce 1993, 181 and 200).
} 
When the Census Bureau added the Hispanic Origin and Ancestry questions in 1980, it also eliminated two related questions from the decennial census: mother's and father's birthplaces. This substitution proved to be a fateful decision. Parental birthplaces had been reported in every enumeration from 1880 through 1970. The most obvious reason for dropping parental birthplaces was to keep a cap on the sheer number of questions. Also, the pressure of the ethnic advocacy groups, and hence the attention of politically sensitive officials, was on the two new questions. Finally, no one then could be sure that the number of new immigrants was going to rise as high as it did, and perhaps too there was a feeling that tracking the second generation was an issue decisionmakers of a later decade could worry about. For such reasons, it seems, dropping the parental birthplace questions did not generate consequential opposition. ${ }^{25}$ Or so it must have seemed to decisionmakers in the late 1970 s. $^{26}$

By 1980, the Race question had come to resemble at least two crucial features of the new Ancestry and Hispanic Origin questions: all three relied on subjective identity and all ignored the respondent's generational standing in America. Nor could we distinguish between race and the other two classifications on the grounds that the former meant something distinct because it was rooted in biology. The Procedural History of the 1980 enumeration presents the usual disclaimer: “The concept of race used in recent censuses reflects self-identification by respondents; it does not denote any clear-cut, scientific definition of biological stock” (US Census Bureau 1986, ch. 12, p. 19). In the final analysis, as a matter of origin concepts alone, there was no clear reason for more than one origin question. The distinctive features of the Race and Hispanic Origin question had to do with methodology (especially the likelihood of specific responses), history, and legal standing.

Another feature of the 1980 race question heightened the sense that the differences among these questions was less than clear. The Race question was not in fact labelled with the word “race” (nor “race or color”) as in past enumerations. Instead, the printed question read: “Is this person ...” followed by boxes, each labelled with the name of a race category. In other words,

\footnotetext{
${ }^{25}$ We have not found detailed discussion of the decision to drop the parental birthplace questions.

${ }^{26}$ We return to this theme in the next section.
} 
the race categories were not presented explicitly as races but simply as categories of an undefined classificatory concept.

Dropping the classificatory label is a change that can carry a very broad message. All Americans get the questionnaire with the "race” question and how it is presented to them affects thinking and discourse. The authority with which the census holds up a mirror to the nation may be difficult to measure, but there is no reason to assume it is nugatory. Cutting the question about "racial” origins loose from the label can therefore convey something to respondents (and journalists). It can suggest that the categories found in this question cannot be easily related to one covering concept. Instead these categories are listed because distinctions of different kinds have arisen in American history. And a respondent's being in one or another of these categories may well affect his or her life chances today. Whatever the reasons for the introduction of the unlabeled "race” question in 1980, in retrospect, the shift then seems like an auspicious initiative and precedent that should be carefully considered today.

Why then did Bureau officials settle on that initiative? And indeed what befell it later? They seem to have adopted it primarily (perhaps exclusively) for the reason given in the Procedural History for the 1980 Census.

\begin{abstract}
The word "race" was not used on the 1980 Census questionnaires; instead, the lead-in to item 4 was "Is this person -." This departure from most recent censuses was made at the suggestion of the Bureau's advisory committees, which had noted that some of the categories listed in the question are not generally considered racial groups. (US Census Bureau 1986, ch. 12, p.10)
\end{abstract}

The Procedural History does not tell us which categories under the race question perplexed the advisory committees. Probably they were referring to the new categories, namely to the Pacific Island categories: Hawaiian, Guamanian, and Samoan. Did some Bureau officials also reflect on the inclusion of two new (and overlapping) ethnic origin questions, the increasing array of race categories, and the disclaimers about what a race really was anyway? We have found no evidence that they did.

In any event, the new initiative to avoid the label "Race" was dropped in the very next decennial 
census. So ended, at least for the next two census cycles, part of an effort "to make the intent of the question clearer and improve reporting” (McKenney and Cresce 1993, 174; U.S. Census Bureau 1996, 14-16). So ended, at least for the next two census cycles, the experiment with omitting the "race" label.

\section{RECOGNIZING MULTIRACIAL ORIGINS IN 2000: A BRIDGE FROM THE LEGACIES OF 1980 TO THE RECONSIDERATIONS OF 2020}

At the end of the 1990s, the OMB revised its Directive \#15 to officially acknowledge that one could "mark one or more” race categories (rather than "mark one only") and the new arrangement was introduced in Census 2000. It is first of all worth a backward glance to understand how mixed origins had been handled before that date.

Consider first parental birthplaces, listed prior to 1980. They had always allowed for “mixed parentage” (as it had been called). The native-born child of one parent from Ireland and the other from Germany was of two ethnic origin groups. ${ }^{27}$ Similarly, since 1980 , a person could list as many ancestries as he or she wished. The Census Bureau tabulated a maximum of three of these in 1980 and two since then (Lieberson and Waters 1988, 7-8). ${ }^{28}$

In the long history of the "color or race" question prior to 2000, only black-white combinations had ever been listed, and those only long ago. From 1850 through 1920 the mulatto category was an option in every census except one (1900). And the 1890 Census had actually listed three levels of black-white mixture, by adding categories for quadroon and octoroon. ${ }^{29}$ Beginning in

\footnotetext{
${ }^{27}$ The native-born child of one parent from Ireland and the other parent American-born was also labelled as of mixed parentage. Note, however, that in this case the "mixed parentage" might all have come from one ethnic origin (in this case Irish descent). The mixture would actually have been only in generations since immigration.

${ }^{28}$ See also the Census Bureau website at: http://www.census.gov/population/censusdata/pc80-s1-10/pc80-s1-10.pdf. The Bureau tabulated 17 triple ancestry combinations in 1980, the choices based on prior surveys. Only the EnglishGerman-Irish combination included over a million individuals (1.6 million). Three others included over 500,000.

${ }^{29}$ See also the Census Bureau website at http://www.census.gov/history/www/through_the_decades/questionnaires/ and http://www.census.gov/history/www/through_the_decades/census_instructions/ accessed September 13, 2015. The 1900 failure to list the mulatto category was perhaps a reaction to having listed so much detail 1890 and finding the distinctions unreliable.
} 
1930, only black and white categories were listed. They were accompanied by the instruction to count any noticeable quantity of African origins in the black category. The instruction about blacks in the 1930 Census is occasionally discussed as the triumph of the "one drop rule." But 1930 is very far along in American history for the date of that triumph. The purpose of the mulatto category (and in 1890 of two more categories) had been to achieve the same result: the white category had been reserved for those without black admixture.

The 1930 Census also instructed enumerators to count any other mixed-race individual (that is, involving a mixture other than black and white) in the category in which he or she most easily fit. Later, this guideline was generalized to all groups. Later still, in the era of racial selfidentification, it was directed to the respondent rather than an enumerator. Likewise, it is repeated in the OMB's Directive \#15 (1977).

By the 1970s, one advantage of this emphasis on single, non-overlapping race counts was that evaluation of under-representation in civil rights cases was simplified: someone was either black or white. Indeed, one reason the push for a clearer recognition of the multiracial individual was resisted in the 1990s was the possibility that it would confuse those civil-rights counts. And indeed some of the political support that brought attention to the protest of the multi-racials rested on motivations that went well beyond multi-raciality itself. Specifically, there was an expectation that the change might dilute or confuse the claims of minority race organizations to speak for a well-defined clientele (Perlmann and Waters 2002; Williams 2008). ${ }^{30}$ But not long after the OMB replaced the instruction to "mark one [category] only" with the instruction to "mark one or more," the Department of Justice headed off any such challenges to civil rights legislation by declaring that for purposes of civil rights law, a mixed-race person was to be counted in the minority race category. ${ }^{31}$ This latter decision at Justice had an arbitrary quality to it, but the alternative would have been endless case-by-case challenges as to who qualifies as a minority group member for evaluating under-representativeness. In any case, the Justice

\footnotetext{
${ }^{30}$ On a practical level, one might have thought that the mix of races in the distant American past might have led a great many blacks to select a white and black identity. But in fact few seemed to answer the new race question in this way; instead, most answered with the recent family history in mind.

${ }^{31}$ If two or more minority races had been chosen, the one most relevant to a particular civil rights litigation was to be used.
} 
Department's simplification did not affect the census counts: since 2000, mixed origins have been recognized in the Race question. As already mentioned, they had been recognized in the parentage questions (parental birthplaces) until those were eliminated in 1980 and then in the Ancestry question.

It is worth appreciating that the role of mixed origins in connection with the Hispanic Origin question is much less clear cut. The adjustment in the Race question of Census 2000 allowing the respondent to "mark one or more" was not paralleled by any adjustment in the Hispanic Origin question. Yet much the same issue arises for Hispanic Origin counts. It is worth appreciating the point both for the history of these counts and because the issue will surely arise in connection with expected changes in the 2020 question on ethno-racial origin. The Hispanic Origin question asks whether a person has Hispanic origins, yes or no? This formulation does not allow the respondent to indicate that he or she has both Hispanic and non-Hispanic origins. The point is especially striking because if the answer is yes (of Hispanic origin) the respondent is then instructed to list his or her specific Hispanic origins-Mexican, Puerto Rican, etc. And here the instruction is that if one has multiple Hispanic origins, they can all be listed. Thus one is invited to note that one is part Puerto Rican and part Dominican for example but cannot state that one is part Puerto Rican and part Irish or part Puerto Rican and part Jamaican.

If the Hispanic Origin individual was also of non-Hispanic origins, the fact might well emerge in responses to the Ancestry question. But of course, this cross-question comparison was also true of the Race question prior to the change from “mark one only” to “mark one or more.” In 1980 and 1990, a person reporting “black” (or “white”) under race could “mark one only” on that question but might still report “African” and "Irish” origins on the Ancestry question. Yet this consideration did not stop the advocates of multiracial reporting from demanding the change in the race question itself, nor the OMB from agreeing to the change. The point is that reporting multiple origins under a single, politically charged ethno-racial category can be important to the respondent as well as to the public’s understanding. The Hispanic origin question still fails to permit such reporting. 
Why then was the Hispanic origin question not a target for the same reform as the race question in the late 1990s, a reform that would have allowed the Hispanic origin individual to also be a non-Hispanic individual? The reasons surely have to do with the political contexts of the debate. Probably the minor reason had to do with the concerns over the size of Hispanic counts, the insistence in avoiding anything that would reduce the number of Hispanics counted, or confuse the presentation of the count. This minor consideration alone might well have ensured that the Hispanic Origin question would not be affected by the reform of the late 1990s, but in fact, to the best of our knowledge, the issue of such a change for the Hispanic Origin question never even arose.

The impetus for "mark one or more" came from individuals who refused to accept the choice of being only black or only white for themselves or for their children. Protest about classification focused on this particular mixture. The case of Hispanic/non-Hispanic origins may have been logically similar, but historically and politically it was altogether different. The interracial couples and offspring who brought the challenge were challenging both black and white iconic simplifications dating back centuries. There was nothing remotely like this operating among Hispanics.

Indeed, by 2000, the critical factor among Hispanics directed attention in a different direction altogether: towards the recent huge Latino immigration. How were these immigrants and their children faring? Issues of later-generation intergroup unions was hardly the pressing concern. Still, by 2000 observers were noticing that Hispanic outmarriage, a measure of joining the mainstream, was well advanced, even among the new second generation; in fact it was two to three times as great as the rate at which blacks were marrying a person of another race.

In any case, the anomaly that one cannot declare oneself Hispanic and non-Hispanic in the context of the Hispanic Origin question may become moot if the Census Bureau moves to a new ethno-racial classification system of the type it has been testing. 


\section{LEGACIES OF THE 1980 ETHNO-RACIAL ORIGIN QUESTIONS}

\section{Eliminating the parental birthplace questions}

It is something of a mystery how the decisionmakers could have dropped the parental birthplace questions. We have speculated that three considerations might have been relevant: the need to keep a cap on the total number of origin questions; the attention ethnic advocacy groups focused on the new Hispanic Origin and Ancestry questions; and perhaps a mistaken view that the number of new immigrants would not continue to surge over coming years. In fact, by then the long-term impact of the 1965 Hart-Cellar Act was well on its way to recreating a new mass immigration. A majority of these new immigrants came without special educational attainments or wealth. Also the great majority were nonwhites-Hispanics and Asians. And they entered a very different economy than the one that greeted immigrants in earlier times (with a smaller proportion of jobs for low-skilled workers). How would the American-born children of these immigrants fare? In the midst of the largest immigrant wave in American history, the country had given up its best tool for tracking the progress of incorporating the next generation.

With the parental birthplace questions, we can distinguish how well three very distinct groups of people fare on social and economic measures: immigrants, their native born children, and the later-generation descendants of immigrants from a particular national origin (third and later generations). Without the parental birthplace questions, we can only divide national-origin groups between immigrants and everyone born in the United States. The second-generation group cannot be distinguished from third and later generations. We cannot even know the size of the second generation, much less how differently it is faring in social and economic terms from later-generation descendants. To put it differently, we proceed as though we believed that only origin group and not growing up in an immigrant family matters, that only the former and not the latter influences the wellbeing of the US-born children of recent Mexican or Chinese or Irish arrivals.

True, the Current Population Survey (CPS, jointly administered by the Census Bureau and the Bureau of Labor Statistics) began asking the parental birthplace questions in the 1990s as an attempt to minimize the damage done by eliminating the questions from the decennial census in 
an era of great immigration. But it is important to appreciate two differences between the CPS and the census: size and targeted population. As to size, consider the situation around the decennial census year 2000. The combined CPS samples for the four years 1998-2001 reached 150,000 households. For Census 2000, a 6\% sample of all American households received the "long form” questionnaire-several million households, including nearly seven million people. The long form included the barrage of questions that probe social and economic well-being in great depth: education, occupation, self-employment, unemployment, welfare, the many sources of annual income, homeownership, family and household poverty levels, health measures, and specific kinds of institutionalization. The ability to discern the progress of the children of immigrants on this rich array of measures is what is at stake. The CPS also covers many of these measures. But the radically smaller size of that survey compared to the census makes it much less useful for any analysis below the national or regional level. The census data are reliable for towns, parts of cities, and rural parts of states. The size factor also makes the CPS much less useful even at the national level for the analysis of complex factors-such as the many factors that go into determining Mexican-American poverty levels in central cities.

Since 2001, the Census Bureau has replaced the decennial census long form, the detailed questionnaire that went to 6\% of the population, with the American Community Survey (ACS). This survey includes the same questions that the long form did, but reaches $1 \%$ of the population every year. Thus, it includes a smaller fraction of Americans from the year of the decennial census (1\% rather than 6\%), but it provides annual information in what is still a huge sample, and a sample that when aggregated across a decade amounts to fully $10 \%$ of Americans. And so today, restoring the parental birthplace questions to the census in order to reap the benefits of the vastly larger size of census compared to CPS surveys means adding those questions to the ACS, the successor of the decennial census long form questionnaire.

The second great advantage of the census over the CPS is the targeted population of each. Whereas the census counts the entire population, the CPS is restricted to the civilian noninstitutionalized population. When we want to know the fate of the second generation, it is important to ask, for example, how many are enlisted in the military or how many are incarcerated. And these subpopulations affect many other questions. Thus if we use the CPS to 
determine the proportion of second-generation Hispanics (or Mexican-Americans) who fail to complete high school, our results will be overly optimistic because the incarcerated population is not included in the CPS and that population includes a much higher proportion of high school dropouts than the non-incarcerated population. By how much will our estimate be overly optimistic? In the absence of the parental birthplace questions on the ACS, we cannot be sure. We cannot say what proportion of the native-born Hispanics (or Mexican-Americans) are second generation, how many of those second-generation members dropped out of high school, and how many of those dropouts are incarcerated.

\section{The Ancestry question: ambiguous data and uncertain sources of support}

Of all the changes in 1980, the Ancestry question has proven to be the least relevant to understanding the connections between group origin and life chances, and its historical value for understanding the genealogical record, presumably a lower federal priority, is limited too. Its counts are not required for civil rights law in general or affirmative action in particular. The OMB directive on the collection of racial and ethnic data does not call for such data.

The Ancestry counts for nonwhite groups largely duplicate those of the Race and Hispanic origin questions. Nevertheless, to understand possible sources of support for the question, it is worth noting in passing two interesting exceptions to this generalization, even if they do not influence federal policies. First, the question provides a second (lower) count of those who identify as Hispanic. As we have seen, the Hispanic Origin question presents a forced yes/no choice about that origin. By contrast, the Ancestry question calls for ethnic descent generally; it only mentions Hispanic options among many examples of Ancestry. Several million fewer people declare themselves to have Hispanic origins on the latter question. Second, until the Bureau introduced the Ancestry question, people with Native American origins could report these only in terms of race. Now, millions (overwhelmingly white by race) declare that they have some Native American ancestry themselves. Indeed, those reporting such ancestry are several times as numerous as those who identify as Native American by race. Thus while the Ancestry question is not legally necessary for federal policy with regard to nonwhite Americans, it may be of some interest and supported especially by advocates for Native Americans. 
The greatest contribution of the Ancestry question unquestionably has been for non-Hispanic whites. No doubt it was reflections such as this that explain why the "ethnic desk" in the Carter White House (in Louis Kincannon's description cited earlier) kept ancestry on the questionnaire. Only here would their national origins be captured past the second generation. And indeed, a point we return to below, after the removal of the parental birthplace questions, only ancestry provides any information on the national origins (or ethnic origins of any kind) for native-born non-Hispanic whites.

Yet we should be clear on the limited value of the Ancestry question for understanding the lines of descent and the current self-identification of those with European ancestries. Still less do these results illuminate connections between national origins and poor life chances. Indeed, what they underscore is above all the declining salience of European ethnic origins after many generations of assimilation and intermarriage. By 2010, even the descendants of the last European immigrant wave, those from the south and east of the continent, were three, four, or five generations from the relevant immigrant ancestor. A fourth- or fifth-generation descendant of any European stock is overwhelmingly likely to also be the descendant of multiple other stocks, most commonly also European. ${ }^{32}$ Indeed, such descendants typically cannot know much about their messy lines of descent; they report about whatever ancestor is known. This long assimilative process not only guarantees multiple rather than single ethnic origins; it also raises skepticism about the strength of any reported self-identification. And finally it makes it hard to find connections between ethnic origins and life chances. All these considerations are still more important for the descendants of arrivals from northern and western Europe, since they are mostly descended from still-earlier immigrant arrivals—decades or centuries earlier—-than those from southern and eastern Europe.

\section{Hispanic Origin and Ancestry data compared}

The Hispanic origin question is less subject than the Ancestry question to the weaknesses just described: there is probably more stability in self-identification, and those identifying as Hispanic are concentrated in lower socioeconomic niches. One reason for these differences was

\footnotetext{
${ }^{32}$ Although increasingly non-European as well, especially Hispanic or Asian.
} 
given by the Mexican-American advocates in the 1960s and 70s: the persistence of discrimination and isolation on the lives of later-generation group members in the American Southwest. A demographically more important reason why the Hispanic Origin question is less subject than the Ancestry question to the weaknesses mentioned is the huge Latino, and especially Mexican, immigration of recent decades. The families of immigrants and their children — the first and second generation—are less likely to have mixed origins than are families farther removed from immigration. They are also especially likely to reflect the connection between ethnic origins and poorer life chances-especially when the immigrants arrive (as most Hispanic immigrants do) without special educational advantages or capital for entrepreneurship. And to the extent that the immigrants are undocumented, it is that much harder for them to make their way into the middle class, for example because they cannot rely on the protection of the legal system. At the moment then, in contrast to the initial rationale for it, the Hispanic Origin question's connection to recent immigration rather than to historically distant immigrant origins helps explain much of the under-representation of Hispanics in attractive socioeconomic circumstances. The original claim of Latino advocates in the 1970s was that distant origins of the Mexican-Americans in the Southwest negatively influenced their life chances. And this claim had considerable force. However, the recent massive Latino (and in this case especially Mexican) immigration now comprises a very large share of the Hispanic population-a population of first- and second-generation members. These complexities reflect the fact that Mexican immigration in particular is both very old and today is very large.

Moreover, data presented for the Hispanic Origin group can convey the sense that the group in question is, like non-Hispanic blacks, a group under-represented primarily because of a long history of discrimination. And yet, the recent labor-migrant status of so many Hispanic families may well be at least as important to understanding particular social inequalities. A simple example concerns reports dealing with the educational attainment of blacks, Hispanics, and nonHispanic whites. Consider men 25-34 years of age. The Hispanic group includes the fifthgeneration descendent Mexican-American, but it also includes a great many immigrant men whose entire education took place in Mexico or Central America. Their experience tells us nothing about the success of American schools in educating Hispanics today. The point is not to 
let American schools off the hook; there is plenty to say about this issue when good evidence is scrutinized—evidence best restricted to the American-born second generation of Hispanics.

The historical irony here is that more refined data about the immigrants and their children were in fact available until 1980. Both generations could be identified separately through the birthplace and parental birthplace questions. But in 1980, the parental birthplace questions were discarded. Distant origins of the American-born were privileged over near-term origins—just as the latter were becoming critical and the former less important. This situation is a cost of the way the struggle over Hispanic and white ethnic origins played out.

\section{Appreciating the crucial point about the Ancestry question and the non-Hispanic white population today}

Few people realize that since 1980 (when the parental birthplace questions were eliminated) only the Ancestry responses provide any information on the specific national origins of native-born white Americans. Thus to remove the Ancestry question without reintroducing the parental birthplace questions seems altogether impossible to us. The data may be of minimal use for research on social inequalities but it is difficult to imagine that in a nation of immigrants the question will be dropped without both the return of the parental birthplace questions and some other attention to more distant origins (origins three or more generations back). Information on more distant origins, after all, will continue to be collected for the four protected minority groups.

Today "white ethnics" may seem less consequential than "Euro-Americans" or "white Americans." However, the considerations about Ancestry reviewed here suggest that the willingness to test support for the Ancestry question will be low, other things being equal. Moreover, it may well be that for all the ambiguities of the Ancestry data on white Americans another source of support for the question is now consequential: genealogists uncomfortable about losing a giant sample of data on distant origins, whatever its weaknesses. 
In the final section of this paper we suggest that there is reason to hope that these considerations may yet appear in a new light if the Census Bureau settles on a new race question of the type we hope and expect.

\section{RECONSIDERING THE PROBLEMATIC LEGACIES OF 1980: SOLUTIONS FOR 2020}

\section{The Bureau’s “technical” problem with the 1980 legacy}

A consensus may be emerging for an important new change in the federal classification of race and ethnicity. It is being driven by a desire to deal with a particular problem in the current arrangements. This problem might be seen as "merely technical”-except for those officials who have to find a solution to it-but confronting that problem has led to an effort to test alternative questions on ethno-racial origin, and particularly questions that consolidate Race and Hispanic Origin into a single question. ${ }^{33}$

The problem is that huge numbers of Hispanics do not chose any of the four specific race categories-white, black, Asian, or American Indian. Over two-fifths of them select "some other race.” The choice suggests limitations in the categories, but that is not the Bureau's immediate problem. Rather, the problem is that many federal agencies require age-race-sex tabulations from the census for planning purposes. These tabulations in turn only recognize the four race categories mandated by OMB, not “some other race.” The Census Bureau is therefore obliged to create a set of "modified” tabulations in which it must allocate many millions of Americans (virtually all of whom are Hispanics) from "some other race” to one of the four mandated categories. $^{34}$

This pattern of reporting by Hispanics has an intriguing history. Recall that in the 1930 Census “Mexican” had been added to the Race categories. Pressure brought its removal by the next

\footnotetext{
${ }^{33}$ The changes being considered are summarized in Jones (2015); available at: http://www.census.gov/people/news/issues/vol3issue6.html. This section was also stimulated by grappling with Kenneth Prewitt's (2013) arguments.

${ }^{34}$ The estimate is known as the MARS count: Modified Age, Race, Sex count.
} 
cycle, and the Bureau adopted an instruction that "Mexicans are to be regarded as white unless definitely of Indian or other nonwhite race” (US Bureau of the Census 1940). This procedure was continued into the era of respondent-completed census forms. But at that point the Bureau could no longer rely on the enumerator to report that the respondent was white. Some fraction of Mexican-Americans (native and foreign born) described themselves as members of some other race. Apparently, the Census Bureau seems to have recoded these entries to white, in essence following the policy of 1940. However, the number of such recodes is unknown-until 1980. In that year, the Census Bureau decided that given the interest in such topics and the new Hispanic Origin question, it should no longer recode these responses to "white” but instead record the choice of "some other race."35

How much of the current very widespread Hispanic tendency to list oneself in "some other race" preceded the years leading up the introduction of Hispanic Origin in the census and in public awareness? If it was very widespread prior to the 1970s, for example, it may have reflected concepts of race that were somewhat different in Mexico or Latin America. If it was not very widespread, the current prevalence of choosing to list some other race might well reflect more about the US context - the change in Hispanic formulations that the Hispanic Origin itself captured. In the absence of more knowledge than is now available about the census recoding practices prior to 1980 it is impossible to reach conclusions about this point.

In any case, the present reality is that roughly two in five Hispanics report themselves as some other race. And consequently, the Bureau's is obliged to adjust many millions of reports into one of the OMB's mandated racial categories. This is the situation that has led to the Bureau's intriguingly detailed current program of testing other options for the crucial ethno-racial data.

\footnotetext{
${ }^{35}$ There was actually a further interesting complication. In 1980, it did not recode these choices to the standard "other" category. Rather it kept them in a separate recode category: recoded "white" from "other" chosen by Hispanic Origin respondents. This distinction was dropped in 1990, so that all the Hispanics who chose some other race were left as such. It is worth noting that in the IPUMS samples, the 1980 responses are collapsed to white in the general form of the Race codes, whereas from 1990 on they appear as "some other race." In the detailed form of the race variable, they are shown in "some other race" in both 1980 and 1990. I am grateful to helpful clarifications by Tim Moreland at IPUM; see https://usa.ipums.org/usa-action/variables/RACE\#comparability_section
} 
Thus a problem affecting perhaps 5\% of Americans (those Hispanics who list themselves as "some other race") may have a decisive and beneficial influence on the way race and ethnic origin are presented to the American population as a whole. A similar situation triggered the change at the end of the 1990s, when an even smaller proportion of Americans insisted on their right to list themselves as both white and black.

\section{The single-question format when multiple origins are recognized}

Our expectation is that the Census Bureau will find that a single race and ethnicity (race and Hispanic Origin) question will solve its "technical" problem (Hispanics choosing "some other race"). ${ }^{36}$ The solution would presumably bear some resemblance to option B in the 1977 OMB Directive \#15. The new question would have five broad ethno-racial categories: white, black, American Indian, Asian, and Hispanic. Those identifying themselves as of Hispanic Origin would no longer need to find a place for themselves among the other four specific race categories.

But in one respect a single-question format will differ decisively from the 1977 version of option B. Today, respondents will be permitted to include themselves in more than one of the ethnoracial categories. ${ }^{37}$ Indeed, the Bureau is also testing the impact of urging respondents to "mark all that apply” and not only "mark one or more” (Jones 2015). In 1977 option B meant choosing between black (or white) and Hispanic origin. And even in Census 2000 one could not mark both Hispanic and non-Hispanic in one question. But with white, black, and Hispanic all listed in the context of "mark one or more," or even "mark all that apply," the updated version of option B should be more acceptable to ethnic advocates than it would have been in 1977 and also complete the recognition of multiple origins.

\footnotetext{
${ }^{36}$ Most Hispanics who do choose one of the four mandated race categories choose white. The choice often seems to be a default option, meaning "not in the other three mandated race categories; those are for groups to which I do not belong." Faced with the combined test question, almost no Hispanics choose some other race and many fewer choose white (Rios, Romero, and Ramirez 2014; Compton et al. 2013).

${ }^{37}$ This permission is found in all the options being considered in Jones (2015).
} 


\section{Reporting specific ethnic origins}

Another crucial feature of the ethno-racial questions being tested is that they provide a line that asks for specific ethnic origin(s). For American Indians and Asians, the specific origins would be like those requested today on the Race question: tribal membership for the former and specific national origins for the latter (Chinese, Japanese, Samoan, etc.). For Hispanics, the specific origins would be the national origins currently provided under the separate Hispanic Origin question (Mexican, Puerto Rican, etc.). And finally, for blacks and whites the specific origins would be those that are available today under the Ancestry question. For example, blacks might list simply African-American, or Jamaican and Puerto Rican, or Nigerian. Whites might list Irish and/or German. ${ }^{38}$

\footnotetext{
${ }^{38}$ See the discussion in Jones (2015).
} 
Figure 2a. An Example of the Combined Ethno-Racial Origin Question Currently Being Tested for the 2020 Census

\section{What is Person 1's race or origin?}

Mark $囚$ one or more boxes AND print origins.

White - Print, for example, German, Irish, English, Italian, Lebanese, Egyptian, etc. I

Hispanic, Latino, or Spanish origin - Print, for example, Mexican or Mexican American, Puerto Rican, Cuban,

Salvadoran, Dominican, Colombian, etc. I

Black or African Am. - Print, for example, African American, Jamaican, Haitian, Nigerian, Ethiopian, Somali, etc. I

Asian - Print, for example, Chinese, Filipino, Asian Indian Vietnamese, Korean, Japanese, etc. I

American Indian or Alaska Native - Print name of enrolled or principal tribe(s), for example, Navajo Nation, Blackfeet Tribe, Mayan, Aztec, Native Village of Barrow Inupiat Traditional Government, Nome Eskimo Community, etc. 7

Native Hawailan or Other Pacific Islander - Print, for example, Native Hawaiian, Samoan, Chamorro, Tongan, Fijian, Marshallese, etc. 7

Some other race or origin - Print race or origin. 7 
Figure 2b. An Alternative Version Omitting the Label ("Race or Origin") in the Question Stem, and Instructing “Mark All That Apply" Rather than "Mark One or More”

\section{Which categories describe Person 1 ?}

Mark all boxes that apply AND print details in the spaces below.

Note, you may repori more than one group.

Source: Jones (2015)

\section{Implications for the Ancestry question}

A crucial implication of this line for specific national origins has escaped discussion: it may make the Ancestry question redundant. As we argued in earlier sections of this paper, the most important contribution of the Ancestry question is the report of European national origins (however imperfect that report may be). It remains to be seen how fully respondents will utilize the write-in line, but at least in conception, what will appear on that line will be identical to what appears on Ancestry for Euro-Americans. We noted earlier that the Ancestry question also makes two contributions to information on nonwhite Americans. First, it provides a lower count for Hispanic Origins (in the context of a question not targeted to those ethnic origins in particular), and second it allows for the report of Native American origins by people who declare themselves white by race. It is doubtful that the former contribution will generate much support for the Ancestry question. But in any case, it seems plausible that both of these contributions and especially the second might not be lost, because respondents could still write them in, especially on the line under the category "White."

As the Ancestry question appears on the ACS, and not on the full 100\% enumeration, there is no need to resolve the fate of that question in time for the 2020 Census - unless it meant that failing that deadline meant that the impetus for changes had to wait decades more. Indeed, if we ignore this last dismal thought, a good case can be made for investigating the results of a 2020 ACS that included the new ethno-racial question as well as the Ancestry question. A better decision about the Ancestry question could then be made.

\section{Implications for the parental birthplace questions}

By contrast, the reader who has followed us this far will not be surprised to learn that parental birthplace questions should be added to the ACS by 2020. The ability to scrutinize the 
incorporation of immigrants' children would be radically improved over what it has been since 1980. Their wellbeing, judged in terms of the many socioeconomic variables found on the ACS, should wait no longer.

Moreover, note that if Hispanic Origin and Race are to be combined into a single question on the $100 \%$ enumeration, as well as on the ACS, there should be a savings in respondent time and federal expenditure. Once again, our impression is that the link between the parental birthplace questions and the tests of ethno-racial origin questions is not being discussed. But surely it should be. The savings from the substitution of one crucial question for two should help make a strong case for adding the parental birthplace questions to the ACS. At issue are two straightforward, virtually identical, questions for an annual $1 \%$ survey. Moreover, these questions can hardly require detailed testing; quite apart from their use over the century prior to 1980, they have been used in the CPS since the 1990s. If it transpires, as we hope, that the single ethno-racial question can also replace the Ancestry question, still further savings will be possible not long after 2020.

\section{Labelling the new ethno-racial question}

How will the new ethno-racial single question be labelled? Apparently two major alternatives are being tested. One asks for a labelled classification such as "race or origin.” The other leaves the covering conception unlabeled: “which categories describe person 1?” Thus this second alternative restores the experiment of the 1980 Census ("This person is..." followed by the options). As we noted earlier, the decision to avoid labelling the covering classification ("the question stem”) seems to have been taken in 1980 on narrow grounds and abandoned in 1990 on other narrow grounds (both irrelevant to the form of the question in 2020). In any case, today, any number of categories rather than one only could be selected.

It is worth citing the way the Bureau's Nicholas A. Jones, who directs the testing program, summarized the research agenda on the labelling issue: 
The 2015 NCT [National Content Test] will also evaluate the use of different conceptual terms (e.g., origin, ethnicity, or no terms) in the wording of questions. Recent Census Bureau qualitative research found that the terms "race," "ethnicity," and "origin" are confusing or misleading to many respondents, and they mean different things to different people. The 2010 AQE [Alternative Questionnaire Experiment] tested the removal of the term "race" from the question and showed no evidence that removal of the term had any effect on either unit or item response rates. Recent cognitive research tested an open-ended instruction ("Which categories describe you?") and found that respondents did not have issues with understanding what the question was asking. Therefore, an alternative option being explored tests the removal of the terms "race," "origin," and "ethnicity" from the question stem and instructions. Instead, a general approach asks, “Which categories describe Person 1?" (Jones 2015) ${ }^{39}$

Note that the passage deals with two broad issues. First, "qualitative research" shows that "the terms 'race,' 'ethnicity,' and 'origin' are confusing or misleading to many respondents, and they mean different things to different people.” And second, tests with “an open-ended instruction ('Which categories describe you?’) [...] found that respondents did not have issues with understanding what the question was asking.”

We are encouraged by the second finding because it suggests the straightforward solution to the problem uncovered in the first finding. Dropping all the "terms" in the question stem, and particularly dropping "race," is indeed a good way to deal with the problem uncovered in the first finding — namely, the problematic nature of respondents' understanding of the labels. Moreover, in the context of these findings, another consideration is useful. The labels are also problematic because of the way an authoritative federal institution uses them in communicating with every American household. The race term has carried the implication of some sort of biological and anthropological meaning for a very long time. It is no comfort to be told that a diligent respondent can find-somewhere in the Census Bureau (and OMB) texts—a disclaimer that in asking the origins question the Bureau does not mean to convey the meanings found in

\footnotetext{
${ }^{39}$ The NCT is "our primary mid-decade opportunity to compare different design options for race and ethnicity prior to making final decisions about the content of the 2020 Census." The AQE was "the most comprehensive research effort on race and Hispanic Origin ever undertaken by the Census Bureau.” Under of the options being considered, there is no a priori reason to expect that the size of any of the four affirmative action categories should be systematically affected. But of course the Bureau, OMB, and stakeholder groups will be scrutinizing the results to determine that this is indeed the case.
} 
biological or anthropological science. What meanings for these terms does the Bureau (or OMB) mean to convey? And even in the new single-format question, just what is the relation between the write-ins (e.g., national origins, tribal affiliations, etc.) on the lines below the categories (e.g., White, Black, Hispanic, American Indian) and the categories themselves? If the labels still have meaning, why has it become necessary to include races and ethnic origins in one question?

Now is the opportune moment to put all these conceptual distinctions aside in the unified question. Doing so instead of using a question stem like "race or origin" will not have any impact on the uses of the data for civil rights or affirmative action, nor for any other federal purpose. The absence of any label may help convey an important point, namely that the many categories of this single question will not fit under one covering concept. Whether or not the categories in the race question we have inherited ever did is a matter we will finally be able to put aside. All the categories of the unified question have all mattered in American history, and descent through one or another of them continues to influence social and economic wellbeing today. Will this new message be fully clear to respondents? Perhaps not, but we can hope that it will be at least as clear as the messages conveyed in the current labels. 


\section{REFERENCES}

Bohme, Frederick G. 1992. “Oral History of C. Louis Kincannon.” Available at: https://www.census.gov/history/pdf/Kincannon_Oral_history.pdf.

Compton, Elizabeth, Michael Bentley, Sharon Ennis, and Sonya Rastogi. 2013. "2010 Census Race and Hispanic Origin Alternative Questionnaire Experiment.” US Census Bureau. Available at: https://www.census.gov/2010census/pdf/2010_Census_Race_HO_AQE.pdf

Foley, Neil. 2014. Mexicans in the Making of America. Cambridge: Harvard University Press.

Fox, Cybelle, and Thomas A. Guglielmo. 2012. "Defining America’s Racial Boundaries: Blacks, Mexicans, and European Immigrants, 1890-1945.” American Journal of Sociology 118(2): 327-79.

Francis-Fallon, Benjamin. 2012. "Minority Reports: The Emergence of Pan-Hispanic Politics." $\mathrm{PhD}$ diss., Georgetown University.

Glazer, Nathan. 2002. "Reflections on Race, Hispanicity and Ancestry in the U.S. Census.” in Joel Perlmann and Mary C. Waters (eds.), The New Race Question: How the Census Counts Multiracial Individuals, New York: Russell Sage Foundation; New York: Levy Economics Institute of Bard College.

Gratton, Brian, and Emily Merchant. 2015. "La Raza: Mexicans in the United States Census.” paper presented at the Social Science History Association Meeting, November.

Guglielmo, Thomas. 2004. White on Arrival: Italians, Race, Color and Power in Chicago, 1890-1945. Chicago: University of Chicago Press.

Hochschild, Jennifer L., and Brenna Marea Powell. 2008. "Racial Reorganization and the United States Census 1850-1930: Mulattoes, Half-breeds, Mixed Parentage, Hindoos and the Mexican Race.” Studies in American Political Development 22(1): 59-96.

Johnson Jr., Charles. 1974. "Consistency of Reporting Ethnic Origin in the Current Population Survey.” Current Population Survey, US Government Printing Office, Washington, D.C. Technical Paper no. 31.

Jones, Nicholas. 2015. "Update on the U. S. Census Bureau's Race and Ethnic Research for the 2020 Census." in Newsletter, April. Available at:

http://www.census.gov/people/news/issues/vol3issue6.html

Kincannon, C. Louis. 1992. "Interview with Frederick G. Bohme.” Available at: https://www.census.gov/history/pdf/Kincannon_Oral_History.pdf

Lieberson, Stanley and Mary C. Waters. 1988. From Many Strands: Ethnic and Racial Groups in Contemporary America. New York: Russell Sage Foundation. 
McKenney, Namepeo, and Aruthur R. Cresce. 1993. "Measurement of Ethnicity in the United States: Experiences of the U.S. Census Bureau." in Statistics Canada and U.S. Bureau of the Census, Challenges of Measuring an Ethnic World: Science, politics, and reality. Washington D.C: US Government Printing Office.

Mora, G. Christina. 2014. Making Hispanics: How Activists, Bureaucrats and Media Constructed a New American. Chicago: University of Chicago Press.

Office of Management and Budget. 1977. "Directive \#15. Race and Ethnic Standards for Federal Statistics and Administrative Reporting." Available at: http://wonder.cdc.gov/wonder/help/populations/bridged-race/directive15.html

Perlmann, Joel. 2001. "Race or People: Federal Race Classifications for Europeans in America, 1898-1913.” Working Paper 320. Annandale-on-Hudson, NY: Levy Economics Institute of Bard College.

Perlmann, Joel. 2002. "Census Bureau Long-Term Racial Projections: Interpreting their Results and Seeking their Rationale.” in Joel Perlmann and Mary C. Waters (eds.), The New Race Question: How the Census Counts Multiracial Individuals, New York: Russell Sage Foundation; New York: Levy Economics Institute of Bard College.

Perlmann, Joel, and Mary C. Waters. 2002. .), The New Race Question: How the Census Counts Multiracial Individuals, New York: Russell Sage Foundation; New York: Levy Economics Institute of Bard College.

Prewitt, Kenneth. 2013. What is YOUR Race?: The Census and Our Flawed Efforts to Classify Americans. Princeton: Princeton University Press.

Rios, Merarys, Fabian Romero, and Roberto Ramirez. 2014. "Race Reporting among Hispanics: 2010.” Working Paper \#102. Population Division, US Census Bureau, Washington DC. Available at: http://www.census.gov/content/dam/Census/library/workingpapers/2014/demo/POP-twps0102.pdf

Schor, Paul. 2009. Compter et Classer: Histoire des recensements americains. Paris: Editions EHESS.

Skerry, Peter. 2000. Counting on the Census?: Race, Group Identity, and the Evasion of Politics. Washington DC: Brookings Institution Press.

Skrentny, John D. 2004. The Minority Rights Revolution. Cambridge: Harvard University Press.

Snipp, C. Matthew. 2002. "American Indians: Clues to the Future of Other Racial Groups" in Perlmann and Waters." in Joel Perlmann and Mary C. Waters (eds.), The New Race Question: How the Census Counts Multiracial Individuals, New York: Russell Sage Foundation; New York: Levy Economics Institute of Bard College. 
Taeuber, Conrad. 1989. "Interview with Robert Voight.” April 12. Available at: www.census.gov/prod/2003pubs/oh-Taeuber.pdf

US Census Bureau. 1940. Instructions to Enumerators, Population and Agriculture. USGPO, 43.

US Bureau of the Census. 1971. Current Population Report, Series p-20, No. 213 "Persons of Spanish Origin in the United States: November, 1969.” and Series p-20, No. 221, "Characteristics of the Population by Ethnic Origin: November, 1969." Washington DC: US Government Printing Office.

US Census Bureau. 1983. 1980 Census of Population: Ancestry of the Population by State., Washington, DC. Available at: http://www.census.gov/population/censusdata/pc80-s110/pc80-s1-10.pdf

US Census Bureau. 1986. 1980 Census of Population and Housing: Procedural History, GPO, Washington, DC. 12-12, 12-15. Available at:

https://www.census.gov/history/www/through_the_decades/overview/1980.html

US Census Bureau. 1996. 1990 Census of Population and Housing: Procedural History, GPO, Washington, DC. 12-10. Available at: https://www.census.gov/history/pdf/1990proceduralhistory.pdf

US Census Bureau. “Census Instructions.” Accessed September 13, 2015. Available at: http://www.census.gov/history/www/through_the_decades/census_instructions/

US Census Bureau. “Questionnaires.” Available at: http://www.census.gov/history/www/through_the_decades/questionnaires/

Williams, Kim. 2008. Mark One or More: Civil Rights in Multiracial America. Ann Arbor: University of Michigan Press. 